\title{
Soil evaporation studies using mini-lysimeters under differently established rice-wheat cropping sequence in Punjab, India
}

\author{
Rajan Bhatt $^{1}$ and S. S. Kukal ${ }^{2}$ \\ ${ }^{1}$ USF, Usman, Punjab Agricultural University, Ludhiana-141004 (Punjab), INDIA \\ ${ }^{2}$ Department of Soil Science, Punjab Agricultural University, Ludhiana-141004 (Punjab), INDIA \\ *Corresponding author. E-mail: rajansoils@pau.edu \\ Received: June 17, 2016; Revised received: October 10, 2016; Accepted: January 23, 2017
}

\begin{abstract}
Present investigations were carried out in rice-wheat cropping sequence as a whole including the intervening period under divergent establishment methods from 2012-14 at experimental farm of Punjab Agricultural University, Ludhiana, Punjab. Treatments included tillage in wheat viz. zero (ZTW) and conventionally tilled wheat (CTW) - main followed by establishment methods viz. direct seeded rice (DSR) and mechanically transplanted rice (MTR) - sub while tillage in rice viz. puddle (PTR), conventionally tilled (CTR) and zero tilled rice (ZTR) - sub-sub plot. Mini-lysimeters were used for delineating the evaporation trends which found to be fast, low cost, reliable and accurate. During rabi seasons, CTW plots evaporated 15.8 and $3.0 \%$ faster respectively, as compared to the ZTW plots. CTW plots during 2012-13 evaporated 7\% higher than during 2013-14 while ZTW plots evaporated with almost same pace during both the years. After rabi season during intervening period, ZTW plots evaporated 6.8 and $13.6 \%$ faster than the CTW plots during 2012-13 and 2013-14, respectively. During rice seasons, among pure tillage system, zero tilled plots viz. ZTWDSRZT evaporated 21.7 and $22.2 \%$ faster than CTWDSRCT plots during rice 2013 and 2014, while coming over to the mixed tillage systems, CTWDSRZT evaporated 36.7 and $18.4 \%$ faster than the ZTWDSRCT plots. The results from this and other studies suggest that mulching suppress the evaporation losses which further improves the water use efficiency and finally land productivity of the rice-wheat sequence in the region.
\end{abstract}

Keywords: Direct seeded rice, Evaporation, Lysimeter, Rice, Tillage, Wheat

\section{INTRODUCTION}

Soil evaporation is the single most important component of the soil water balance (Freebairn et al., 1987) and techniques to reduce evaporation losses important for partitioning higher fraction of the evapotranspiration components to the productive transpiration component (Bhatt, 2015). Among various challenges in front of sustainable agriculture weeds (Singh et al., 2014; Bhatt and Kukal, 2015b; Singh et al., 2015a,b), sequestration of organic carbon (Du et al., 2015; Zheng et al., 2015), puddability of soils (Yao et al., 2015), degraded soil health (Bhatt and Sharma, 2014), water shortage (Hira et al., 2009; Humphreys et al., 2010, Guan et al., 2015), emerging energy crisis and rising fuel prices; rising cost of cultivation; migration of labor, preference for non-agricultural work (Ladha et al., 2009) and declining agricultural productivity (Abdullah, 2014) are the some important hurdles. The rice-wheat cropping systems (RWCS) occupies 13.5 million hectares ( $\mathrm{m} \mathrm{ha}$ ) in the Indo-Gangetic Plains (IGP) (Gupta and Seth, 2007). In India alone, RW rotation occupies about $10.5 \mathrm{~m}$ ha (Saharawat et al., 2010). The major challenge is to achieve the higher production goals for the ever increasing population with less water, land and labour. Intervening cropping period perhaps the most ignored period, which could be exploited for cultivating the intervening crops which further add to the soil fertility, crop and water productivity and finally livelihood of the farmers. Well documented studies are there in literature, delineating the effect of divergent establishment methods on moisture dynamics during cropping season while moisture dynamics during intervening period has not been documented in detail till now (Bhatt and Kukal, 2015a,b,c). Despite of cropping period, intervening fallow periods has tremendous scope but till now, it was the most ignored period as most of studies concentrates entirely on crop stand periods (Bhatt and Kukal, 2014; Bhatt and Kukal, 2015c) and during intervening period, scientists busy in analysing the effect of earlier imposed treatments on soil health, crop and water productivity. However, the retained moisture in heavily irrigated paddy season during the intervening period is sufficient to germinate the seeds of many rabi and intervening crops (Bhatt and Kukal, 2015b,c). Retaining soil moisture more particularly during the intervening periods is of quite importance for the intervening and upcoming rabi crops (Kaojarern et al., 2004, Bhatt and Kukal, 2014).

Temporal residual soil moisture retention during the intervening periods is of importance for intervening 
crops. A number of published studied are there in literature, demonstrating effect of tillage effects on moisture retention during cropping season while no study upto now covered moisture dynamics during intervening period except one study where after rice during intervening period, zero tilled plots (with 8.1 percent higher straw load) observed to retain higher temporal volumetric soil moisture as compared to conventionally tilled plots (Bhatt and Kukal, 2014) which might be due to the recorded lower soil temperature, which further leads to the lesser tension values and evaporation losses in these plots (Bhatt and Kukal, 2015a). However, more detailed studies on intervening period after double RWCS grown under different RCTs quite helpful to come out with an integrated package of ricewheat establishment methods which helps in practising sustainable agricultural land management (SALM) in the region. Secondly, moisture retention scenario after rice may follow entirely different pattern than after wheat because of reported comparatively higher temperature and shortage intervening period. As per our knowledge, upto now no published literature pertaining to evaporation loss delineation in wheat-rice cropping sequence as a whole including the intervening period is available. Keeping all these in view, present investigations were carried out at experimental farm of Punjab Agricultural University, Ludhiana, Punjab under differently established rice-wheat cropping sequence including the intervening periods (perhaps the most unattended period) for better understanding of the soil evaporation behaviours from 2012-14.

\section{MATERIALS AND METHODS}

Climate: Daily maximum and minimum temperature and pan evaporation were measured at the PAU meteorological station, about $1.5 \mathrm{~km}$ from the experimental site. Rainfall was measured using an automatic rain gauge at the experimental site. The maximum temperature during March-May was slightly higher in 2012-13 than in 2013-14 and the long-term average maximum temperature. It reversed during June-October being lower in 2012-13 than in 2013-14 and long term average particularly in the months of September and October. However, the minimum temperature was almost similar during 2012-13 and 2013-14, being slightly higher than the long term average during June-July and October (Fig. 1a). The pan evaporation in general was lower during both the years of study especially in 2013 -14 . However, it was higher during June-September in 2013-14 than in 2012-13 and long term average (Fig. 1b). The total amount of rainfall was higher (891.6 $\mathrm{mm}$ ) in 2012-13 than in 2013-14 (582.3 mm) (Fig. 1c). However, the rains were better distributed during 2013 -14 (42 rainy days) than during 2012-13 (31 rainy days). The month of June recorded abnormally higher rainfall (296.4 $\mathrm{mm}$ ) during 2012-13 compared to 30.3 mm during 2013-14 (Fig. 1d).

Studied site characteristics: Experimental site was at the research farm $\left(30^{\circ} 54^{\prime} \mathrm{N}, 75^{\circ} 98^{\prime} \mathrm{E}\right.$, and $247 \mathrm{~m}$ above sea level) of Punjab Agricultural University, Ludhiana, India. The soil was sandy loam, non-saline, near neutral with less than $0.5 \%$ organic carbon. The soil had sub-surface compact layer (Bulk density of $1.74 \mathrm{Mg} \mathrm{m}^{-}$ ${ }^{3}$ in 15-30 cm layer) (Table 1)

Establishment techniques for the rice and wheat: The treatments consisted of zero tillage and conventional-tillage wheat as the main plots. The main plots split into two subplots for rice establishment viz. direct -seeded rice (DSR) and mechanically transplanted rice (MTR) where the subplots rice tillage treatments were imposed in the split-split design. Wheat (cultivar PBW -621) was directly drilled at seed rate of $112 \mathrm{~kg} \mathrm{ha}^{-1}$ at row spacing of $20 \mathrm{~cm}$ in standing stubbles (straw load $4.4 \mathrm{t} \mathrm{ha}^{-1}$ ) using Happy Seeder while coming over to rice, cultivar PR-115 established as puddle (PTR), dry-till (CTR) and zero-till (ZTR) under both the establishment methods viz. direct-seeded and mechanical transplanting. For wet seeding, pre-germinated seeds were sown using drum seeder@40 kg ha ${ }^{-1}$ at row spacing of $20 \mathrm{~cm}$ (Bhatt and Kukal, 2015d). For mechanical transplanting, the 30 -d old seedlings (sown at the same date as in DSR) were transplanted using mechanical transplanter at $30 \mathrm{~cm} \times 17 \mathrm{~cm}$ spacing. Fertilizers were applied as per the recommendations of the PAU, Ludhiana depending upon their soil test reports. The recommended cultural practices of PAU were followed to ensure proper weed, insect and pest control. Hand weeding was done to ensure that weeds did not affect evaporation trends in different plots.

Mini-lysimeters for delineating the evaporation trends: The evaporation from the soil surface of growing crop was measured using "Mini-lysimeter". The mini lysimeter consisted of two cylindrical PVC tubes. The outer tube was $0.16 \mathrm{~m}$ in diameter and $0.20 \mathrm{~m}$

Table 1. Basic physico-chemical properties of experimental farm of Punjab Agricultural University, Ludhiana, Punjab.

\begin{tabular}{|c|c|c|c|c|c|c|c|c|c|}
\hline \multirow{2}{*}{$\begin{array}{l}\text { Depth } \\
\text { (cm) }\end{array}$} & \multirow{2}{*}{$\begin{array}{c}\text { Sand } \\
(\%)\end{array}$} & \multirow[t]{2}{*}{ Clay (\%) } & \multirow{2}{*}{$\begin{array}{c}\text { pH } \\
(2: 1)\end{array}$} & \multirow{2}{*}{$\begin{array}{c}\text { EC } \\
(2: 1)\end{array}$} & \multirow{2}{*}{$\begin{array}{l}\text { O.C } \\
(\%)\end{array}$} & \multicolumn{3}{|c|}{$\begin{array}{c}\text { Available nutrients } \\
\left(\mathrm{kg} \mathrm{ha}^{-1}\right)\end{array}$} & \multirow{2}{*}{$\begin{array}{c}\mathrm{Db} \\
\left(\mathrm{Mg} \mathrm{m}^{-3}\right)\end{array}$} \\
\hline & & & & & & $\mathrm{N}$ & $\mathrm{P}$ & $\mathrm{K}$ & \\
\hline $0-15$ & 64.7 & 11.3 & 7.26 & 0.25 & 0.45 & 341.2 & 15.2 & 250.8 & 1.66 \\
\hline $15-30$ & 65.9 & 11.3 & 7.23 & 0.31 & 0.44 & 332.8 & 14.2 & 218.6 & 1.74 \\
\hline $30-60$ & 66.8 & 12.6 & 7.31 & 0.32 & 0.35 & -- & -- & -- & 1.59 \\
\hline $60-90$ & 67.6 & 12.7 & 7.18 & 0.26 & 0.37 & -- & -- & -- & 1.63 \\
\hline $90-120$ & 68.2 & 12.3 & 7.01 & 0.34 & 0.34 & -- & -- & -- & 1.57 \\
\hline $120-150$ & 68.8 & 11.9 & 7.08 & 0.33 & 0.32 & -- & -- & -- & 1.61 \\
\hline
\end{tabular}



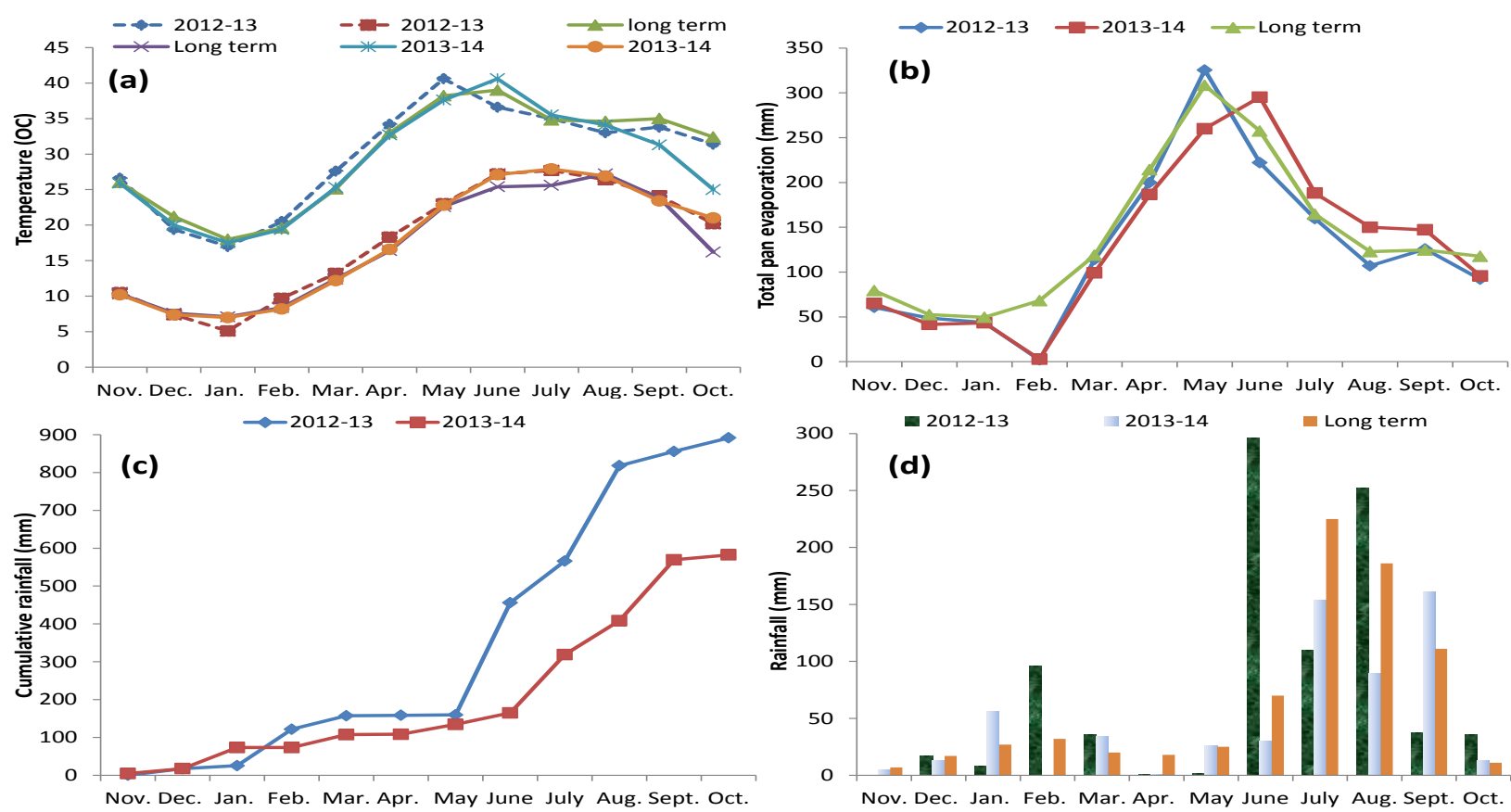

Fig. 1. Mean monthly maximum and minimum temperatures (a), pan evaporation (b), cumulative rainfall (c) and monthly rainfall distribution (d) during the study period (2012-14).

long, whereas the inner tube was $0.102 \mathrm{~m}$ in diameter and $0.20 \mathrm{~m}$ long. The inner tube was covered by porous end cap at the bottom end, whereas the outer was open at both the ends. The cylindrical auger was used to make a hole of diameter equivalent to that of the outer PVC tube which was inserted in the hole of $0.20 \mathrm{~m}$ long. The undisturbed soil cores were obtained in the inner PVC tube at weekly interval during wheat season and after every irrigation/rainfall during rice season. The end caps was put on the bottom end of the inner tube and placed in the outer tube. The weight of the inner tube was recorded daily at 0.900 hours (Fig. 2d). Mini-lysimeters were used (Fig. 2a-d) in the selected treatments to work out daily mm of water evaporated below the wheat and rice canopy which was capped and placed in outer pipes of bigger diameter The purpose of the outer cap was to provide a location within the crop where evaporation could be regularly measured. After every heavy irrigation or rain $(>4.0$ $\mathrm{mm}$ ), lysimeters were refilled and for this, lysimeter were inserted into the different plots (where rice-wheat sown using different establishment methods) with hammer (Fig 2a) and then removed using the chainpulley arrangement (Fig $2 b$ ). The above ground portion of any small weeds that may have been growing in the mini-lysimeters was cut at the soil surface and removed. The mini-lysimeters were carefully removed without disturbing the soil inside lysimeter, the bottom was levelled off, the outsides of the cylinders were cleaned and dried, and a clean cap was fitted to the bottom. Each lysimeter was weighed (Fig 2d) and then placed in outer cap in the experimental plot. During weighing care was taken to ensure that no damage occurred to the soil surface. Further, it is assumed that lysimeter soil representing the surrounding soil from which it is sampled and great care taken to ensure that this assumption is justified. The water balance may then be written as-

$\mathrm{I}-\mathrm{R}-\mathrm{D}-\mathrm{E}=\Delta \mathrm{S}$

Where, I = Rainfall inputs, $\mathrm{R}=$ Surface runoff, $\mathrm{D}=$ Drainage, $\mathrm{E}=$ Evaporation, $\Delta \mathrm{S}=$ Change in the moisture content within the sampled soil in lysimeter.

After a rainfall which wets but not saturates the soil profile we assumed $\mathrm{I}=0, \mathrm{R}=0$ and further it is reasonable to assume $\mathrm{D}=0$ then after all the final equation 2 appeared as

$-\mathrm{E}=\Delta \mathrm{S}$

$\mathrm{E}=-\Delta \mathrm{S}$

Hence, the change in the weight of the lysimeter placed in a particular plot directly indicating the evaporation losses occurred from that plot during last 24 hours.

Calculations for evaporation delineation: Generally, this part is lacking and thus reproduction of the carried out work is quite difficult for the others especially budding scientists which are working on the same track under texturally divergent soils under different agroclimatic regions.

As far as calculations are concerned, different lysimeters were installed under differently established methods.

Weight of the Lysimeter + Soil (Day 1) $=$ A gm

Weight of the Lysimeter + Soil (Day 2) = B gm

Weight of the water evaporated after 24 hours $=\mathrm{A}-\mathrm{B}=$ $\mathrm{X}$ gm (suppose it is $13 \mathrm{gm}$ )

$1 \mathrm{~g}=1 \mathrm{~cm}^{3}\left(13 \mathrm{~g}=13 \mathrm{~cm}^{3}\right)$ 
Now for calculating $\mathrm{cm}$ of water evaporated after 24 hours under different establishment methods, we have to divide $\mathrm{cm}^{3}$ with the area of the lysimeter $\left(\Pi \mathrm{r}^{2}\right) \mathrm{cm}^{2}$ where $r$ is the radius which is supposed to be $7.5 \mathrm{~cm}$. Hence, $\mathrm{cm}$ of the water evaporated $=13 \mathrm{~cm}^{3}=0.073 \mathrm{~cm}$

$$
3.14 \times 7.5 \overline{\mathrm{cm} \times 7.5 \mathrm{~cm}}
$$

For converting $\mathrm{cm}$ of water evaporated into $\mathrm{mm}$, the figures with $\mathrm{cm}$ units need to be multiplied with 10 . Thus, mm of water evaporated from a particular plots under a particular treatment during the last 24 hours= $0.073 \times 10=0.73 \mathrm{~mm}$

By employing the above calculation part, one could calculate the $\mathrm{mm}$ of water evaporated during last 24 hours from the plots established using different resource conservation technologies.

\section{RESULTS AND DISCUSSION}

During wheat 2012-13: Initially upto 29 DAS, evaporation losses in CTW and ZTW plots were at par but afterwards the later plots reported to had consistently lower evaporation losses as compared to the former plots (Fig. 3a). It was mainly due to retention of the straw mulch of $4.4 \mathrm{t} \mathrm{ha}^{-1}$ at the soil surface which hinders direct hitting of the hot sunrays onto the bare soil surface, regulated the soil temperature, restricts free diffusal of the water vapours out of the soil and reduces the wind speed near to the soil surface, thereby reduces the vapours lifting capacity of the air (Bhatt and Khera, 2006). Total evaporation losses during the season observed to be $16 \%$ higher in the CTW plots as compared the ZTW plots (Fig 4a). With lower evaporation losses, higher fraction of the total ET water is partitioned towards the transpiration which directly might be responsible for the higher yields in the ZTW plots if weeds properly controlled well in time otherwise this moisture is utilised quickly by them and resulted in lower grain yield in the ZTW even after

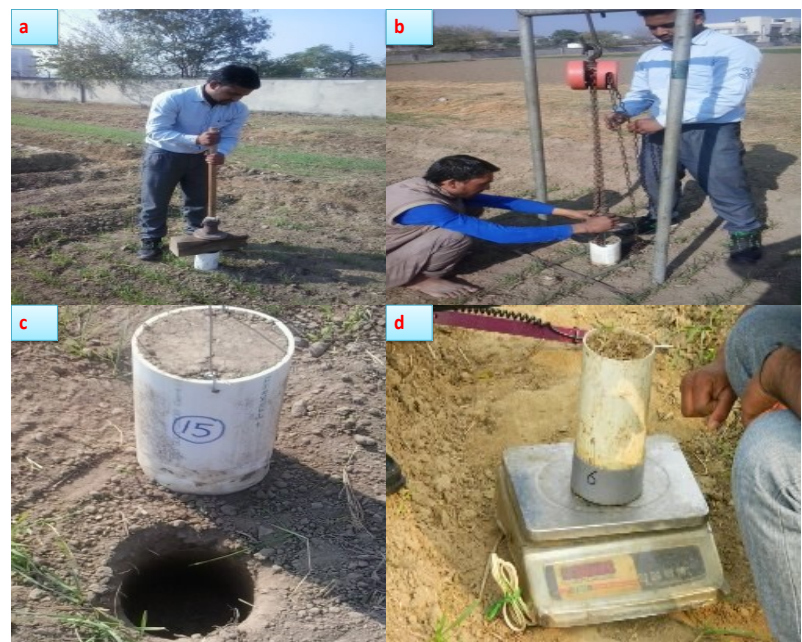

Fig. 2. Installation and measurement procedure for mini lysimeters (a) filling of lysimeter, (b) lifting of filled lysimeter using chain-pulley arrangement, (c) filled lysimeter, (d) weighing of lysimeter. conserving higher fraction of the moisture (Bhatt et al., 2016). Soil evaporation in unmulched wheat constituted a similar proportion of total ET (Singh et al., 2011). Some other workers viz. French and Schultz, 1984; Siddique et al., 1990 reported the same finding depending upon the percent ground cover, crop type, fertilizer strategy and time of sowing, climate, and soil hydraulic properties. Crop canopy architecture such as row spacing can also affect soil evaporation (Es) as a proportion of ET (Eberbach and Pala, 2005). In the mulched plots, sufficient mulch remained to interfere with vapour loss from the soil surface, resulting in lower Es. As far as rate of mulch load is concerned, it was observed in the laboratory studies that $2 \mathrm{t} \mathrm{ha}^{-1}$ of fresh mulch was effective in reducing Es (Gill and Jalota, 1996). In the present investigations, the reduction in the rate of evaporation was so small that duration of Stage 1 evaporation so short and which nonsignificantly reduce cumulative Es over this period. These results align with the findings of Yunusa et al. (1993) who suggested that mulch is effective only in the early periods of growth when canopy cover is small. Initially rate of Es after soil wetting to be lower with mulch than without mulch, but later, the Es from mulched soil slightly exceed that from non-mulched soil (Jalota and Prihar, 1990) which might be because of greater water retention by the soil in the initial stages of drying. However, in the current investigation, Es from the mulched crop never exceeded that from the non-mulched crop, despite the fact that water content of the surface soil in mulched plots was usually higher than unmulched plots.

During intervening period after wheat 2012-13: After wheat 2013-14, earlier retained $4.4 \mathrm{t} \mathrm{ha}^{-1}$ residue load decomposed to $2.2 \mathrm{t} \mathrm{ha}^{-1}$ and it observed that zero tilled plots with this straw loads were not effective to conserve the moisture to a depth of $30 \mathrm{~cm}$ for a prolonged duration. Lower straw loads, continuity of soil pores, preserved higher moisture during previous wheat season, higher soil surface temperature during intervening period were compounded to had higher evaporation while in conventionally tilled plots recorded lower temperature, discontinuity of soil pores hinders the moisture supply from lower depths were the main factors responsible for conserved higher soil moisture during the intervening period (Fig. 3b). Soil temperature reported to be $2.2 \%$ higher in $\mathrm{ZT}$ plots. Evaporation losses reported to be $7 \%$ higher in ZT plots respectively as compared to the $\mathrm{CT}$ during the intervening period after wheat 2012-13 (Fig. 4b) and this further advocated by reported $10.3 \%$ higher volumetric water content in the CTW plots at $7.5 \mathrm{~cm}$ soil depth (Bhatt and Kukal 2015a).

During rice 2013: Initially up to the 11 DAS, all the establishment plots had almost similar evaporation losses but afterwards DSRZT plots under both tillage systems in wheat viz. CTW or ZTW reported to evapo- 

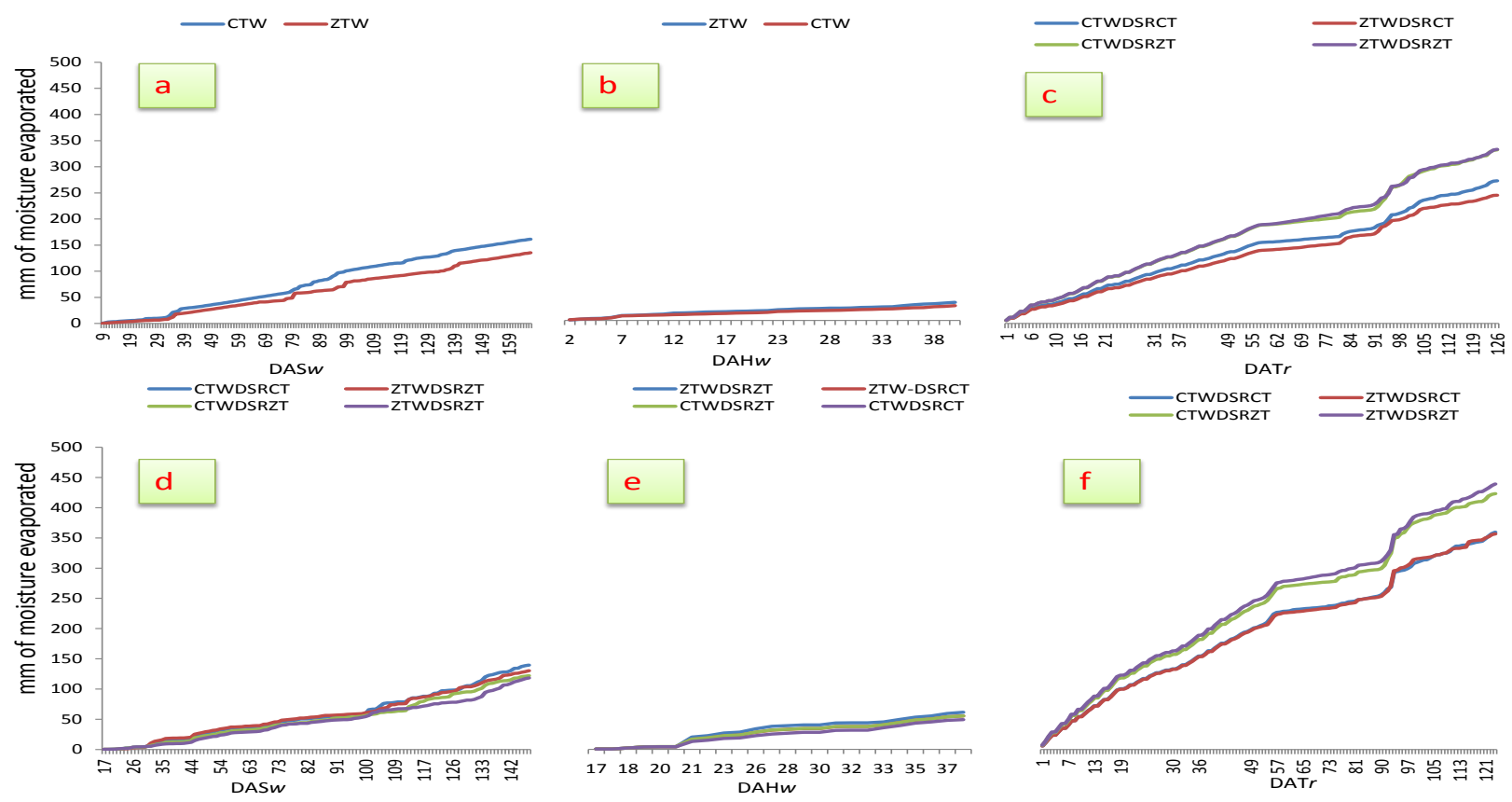

Fig. 3. Evaporation trends under different establishment methods in wheat 2012-13 (a) and wheat 2013-14 (d), intervening periods after wheat 2013 (b) and wheat 2014 (e) and during rice-2013 (c) and rice-2014 (f). (DASw Days after sowing of wheat, DAHw Days after harvesting of wheat, DATr Days after transplanting of rice).

rate faster than that of DSRCT plots. However, CTWDSRZT and ZTWDSRZT plots reported to evaporated with the same pace which reported to be $5.2 \%$ higher as compared to the CTWDSRCT and ZTWDSRCT (Fig. 3c). In general, ET losses contributed $27 \%$ of the total water inputs viz. irrigation + rains. Averaged across the wheat establishment plots, DSRZT plots had $28.9 \%$ higher soil evaporation as compared to the DSRCT plots (Fig. 3c) which is mainly because of the non-significant straw loads, continuity of the soil pores and earlier conserved higher soil moisture during the rabi season. Among pure tillage systems, ZTWDSRZT plots evaporated $22 \%$ faster than CTWDSRCT while among the mixed systems CTWDSRZT plots evaporated $37 \%$ faster as compared to the ZTWDSRCT plots (Fig 4c).

During wheat 2013-14: In the second year of investigation, double ZT plots observed to save one irrigation as compared to other establishment methods which was mainly because of recorded lower evaporation in these plots. On an average across the season, among pure tillage systems, CTW plots evaporates 3\% faster as compared to the ZTW plots and this was mainly because of presence of $4.4 \mathrm{tha}^{-1}$ straw load on the soil surface while losses from mixed tilled plots observed to be remain within the pure tilled plots (Fig. 3d). On an average, the evaporation losses during the wheat 2012-13 reported to be higher than during the wheat 2013-14 (Fig 4a\&d) and it was because of reported higher maximum recorded temperature at the site. As far as cumulative evaporative moisture under divergent tillage scenario concerned, non-significant differences reported during 2013-2014 (Fig. 4d). Evaporation loss- es were 7\% higher in CT plots during 2012-13 than wheat 2013-14 while losses from ZTW plots appeared to be same during both wheat seasons. Rice straw mulch had a pronounced effect on Es after rain and irrigation. After the first irrigation, mulch greatly suppressed Es, principally via Stage 1 evaporation. Stage 2 evaporation appeared to be much less influenced by the presence of mulch. Higher or similar wheat yield under rice straw mulch was also reported in other studies in the same environment (Sidhu et al., 2007; Sharma et al., 2008; Yadvinder-Singh et al., 2008). The higher yields in mulched plots were probably due to increased soil water avail- ability compared with the non-mulched treatments. Soils in un-mulched plots dried at a faster rate than the mulched plots (Bhatt and Khera, 2006). Moisture conservation benefits in mulched plots were reflected in the growth and yield parameters in 2012-2-14 during the rabi seasons (Bhatt and Kukal, 2016).

During intervening period after wheat 2013-14: During intervening period after wheat 2013-14, evaporation trend observed to varies as ZTW-ZTDSRZTW $>$ CTW-CTDSR-CTW > ZTW-CTDSR-ZTW (Fig 3e). Zero tilled (ZTW) wheat evaporates $12.8 \%$ higher (Fig. 4e) because of reported 2.1\% higher soil temperature than the conventionally tilled (CT) wheat plots during intervening periods after wheat 2013-14 (Bhatt and Kukal, 2015b). Soil matric potential was reported to be $28 \%, 18 \%$ and $18 \%$ higher in ZTW plots at 10, 20 and $30 \mathrm{~cm}$ soil depths, respectively. Recorded water depths upto $7.5 \mathrm{~cm}$ of soil surface was $10.3 \%$ higher in CTW plots in comparison to the ZTW during the intervening periods (Bhatt and Kukal, 

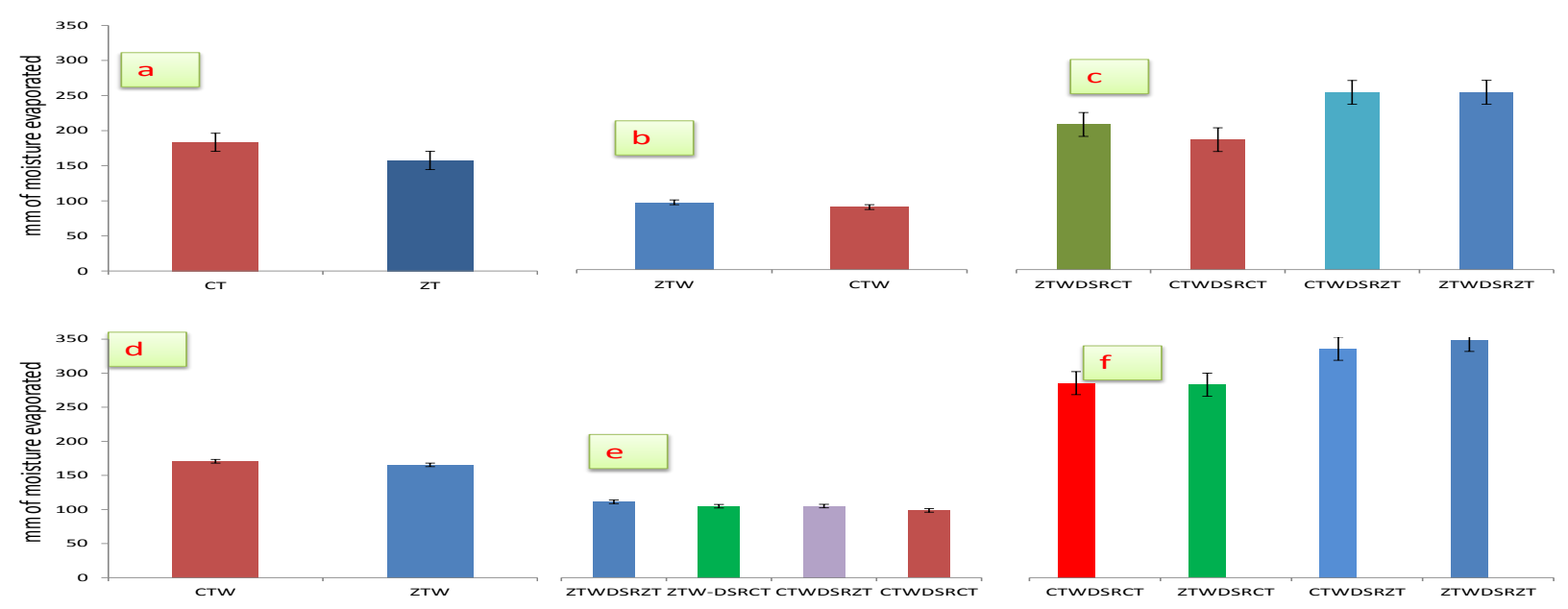

Fig. 4. Cumulative evaporative moisture patterns under different establishment methods in wheat 2012-13 (a) and wheat 201314 (d), intervening periods after wheat 2013 (b) and wheat 2014 (e) and during rice-2013 (c) and rice-2014 (f). (DASw Days after sowing of wheat, DAHw Days after harvesting of wheat, DATr Days after transplanting of rice).

2015b). The reported higher evaporation losses in triple ZT system as compared to the other two alternative methods was mainly because of the continuity of the soil pores and recorded higher soil temperature while in CT systems the regularity of the soil pores was disturbed by tillage which prohibited continued supply of moisture from the deeper layers to the surface soil (Bhatt and Kukal, 2014a). Further evaporation losses pragmatic to be higher (7.6\%) in ZTW plots (Fig. 1d), because of recorded lower mulch loads, higher surface temperature and continuity of soil pores in compare to CTW plots (Bhatt and Kukal, 2015b).

During rice 2014: Among pure tillage systems, ZTW plots evaporates $22.2 \%$ higher as compared to that of the CTW plots however, coming to the mixed tillage systems CTWDSRZT plots evaporates $18.6 \%$ faster than that of the ZTWDSRCT plots (Fig. 3e and 4e). However, CTWDSRZT and ZTWDSRZT plots reported to evaporated $2.4 \%$ higher as compared to the CTWDSRCT and ZTWDSRCT. Across the whole rice season remarkable differences visible under different establishment methods while evaporation losses under ZTWDSRCT $(281.7 \mathrm{~mm})$ reported to be at par with CTWDSRCT plots $(283.9 \mathrm{~mm})$ and these were significantly lower as compared to the evaporation losses under the CTWDSRZT (334.2 $\mathrm{mm})$ and ZTWDSRZT (347 mm) which was mainly because of no straw load at surface, continuity of the soil pores and conserved higher soil moisture in the later plots (Fig. 4e). The reported studies in the rice season at experimental farm of Punjab Agricultural University, Ludhiana, Punjab clearly delineated the importance of the mulch as without mulching even ZT plots experienced higher evaporation losses (Bhatt and Kukal, 2016).

\section{Conclusion}

The present study delineated that even slight mulch loads could conserve considerable soil moisture, especially right after an irrigation/rainfall. Initially, bare soil lost moisture content quickly as compared to the un-mulched plot. The mulching techniques $-\mathrm{a}$ low cost technique conserve moisture, improves the water use efficiency and water productivity. Further to monitor evaporation trends, mini-lysimeter could be used but its results can't be extrapolated in texturally divergent soils because of their empirical behaviour. Our results emphasized that even zero tilled plots without straw mulching during the intervening periods, dried/ evaporates faster even than that from the CTW plots. Thus, straw mulching is the only factor for zero tillage technology to become resource conservation technology which further improved the declining water use efficiency, land and water productivity, and finally livelihoods of the farmers by conserving higher fraction of the soil moisture in the region.

\section{ACKNOWLEDGEMENTS}

The authors are indebted to Dr. Liz Humphreys and Dr. Sudhir Yadav for providing technical guidance; to Dr. Naveen Gupta and Mr. Varun Srivastava for providing technical help at the site. Further, support received from the department of Soil Science, PAU, Ludhiana during the course of investigation fully acknowledged.

\section{REFERENCES}

Abdullah, A.S. (2014). Minimum tillage and residue management increase soil water content, soil organic matter and canola seed yield and seed oil content in the semiarid areas of Northern Iraq. Soil Till Res., 144:150-155

Bhatt, R. and Khera, K.L. (2006). Effect of tillage and mode of straw mulch application on soil erosion losses in the submontaneous tract of Punjab, India. Soil Till. Res., 88:107- 115

Bhatt, R. and Kukal, S.S. (2014). Moisture retention trends during the intervening period of differently established rice-wheat cropping pattern in a sandy loam soil. Inter. 
J. Farm Sci., 4(2): 7-14

Bhatt, R. (2015). Soil water dynamics and water productivity of rice-wheat system under different establishment methods. Dissertation submitted to Punjab Agricultural University, Ludhiana, Punjab, India

Bhatt, R. and Kukal, S.S. (2015a). Tillage residual effects on soil moisture dynamics after wheat during intervening period in rice-wheat sequence in South-Asia. Green Farming, 6(4): 744-747

Bhatt, R. and Kukal, S.S. (2015b). Soil moisture dynamics during intervening period in rice-wheat sequence as affected by different tillage methods at Ludhiana, Punjab, India. Soil and Environment, 34 (1): 82-88

Bhatt, R. and Kukal, S.S. (2015c). Soil temperature, evaporation and water tension dynamics at upper vadose zone during intervening period. Trends Biosciences, 8(2): 484-489

Bhatt, R. and Kukal, S.S. (2015d). Direct seeded rice in South Asia. In: Eric Lichtfouse (ed.) Sustainable Agriculture Review, 18: 217-252

Bhatt, R. and Kukal, S.S. (2016). Tillage and establishment method impacts on land and irrigation water productivity of wheat-rice system in North-west India. Experi Agric. (In Press) DOI:10.1017/SOO14479716000272.

Bhatt, R., Kukal, S. S., Arora, S., Busari, M. A. and Yadav, M. (2016) Sustainability issues on rice-wheat cropping system. Inter J. Soil and Water Conservation Research, 4: $68-83$

Du, Z., Ren, T., Huc, C. and Zhang, Q. (2015). Transition from intensive tillage to no-till enhances carbon sequestration in microaggregates of surface soil in the North China Plain. Soil Till. Res, 146: 26-31

Gill, B.S. and Jalota, S.K. (1996). Evaporation from soil in relation to residue rate, mixing depth, soil texture and evaporativity. Soil Technol, 8: 293-301

Guan, D., Zhang, Y., Mahdi, M., Kaisi, A., Wang, Q., Zhang, M. and Li, Z. (2015). Tillage practices effect on root distribution and water use efficiency of winter wheat under rain-fed condition in the North China Plain. Soil Till. Res., 146: 286-295

Gupta, R. and Seth, A. (2007). A review of resource conservation technologies for sustainable management of the rice-wheat cropping system of the Indo-Gangetic plains. Crop Prot. 26: 436-447

Hira G.S. (2009). Water management in northern states and the food security of India. J. Crop Improve., 23: 136157

Humphreys, E., Kukal, S.S., Christen, E.W., Hira, G.S., Singh, B., Sudhir-Yadav. and Sharma, R.K. (2010). Halting the groundwater decline in north-west Indiawhich crop technologies, will be winners? Adv Agron., 109: 156-199

Eberbach, P. and Pala, M. (2005). Crop row spacing and its influence on the partitioning of evapotranspiration by winter-grown wheat in northern Syria. Plant Soil, 268:195-208

Freebairn, D. M., Hancock, N. H. and Lott, S. C. (1987). Soil evaporation studies using shallow weighing lysimeters: Technique and preliminary results. Trans. Mech. Engn. Inst. Australia., 12: 67-72

French, R.J. and Schultz, J.E. (1984). Water-use efficiency of wheat in a mediterraneantype environment. 2. Some limitations to efficiency. Aust. J. Agric. Res., 35:765775 .
Jalota, S.K. and Prihar, S. S. (1990). Effectiveness of tillageinduced soil mulch as influenced by soil type and atmospheric evaporativity. J. Indian Soc. Soil Sci., 38: 583-591

Kaojarern, S., Toan, T.Le. and Davidson, M.W.J. (2004). Monitoring surface soil moisture in postharvest rice areas using C-band radar imagery in northeast Thailand. Geocarto Inter, 19(3): 61-70

Ladha, J.K., Yadvinder-Singh., Erenstein, O. and Hardy, B. (Eds.) (2009). In "Integrated Crop and Resource Management in the Rice-Wheat System". International Rice Research Institute, Los Baños, Philippines, 395pp.

Saharawat, Y.S., Singh, B., Malik, R.K., Ladha, J.K., Gathala, M., Jat, M.L. and Kumar, V. (2010). Evaluation of alternative tillage and crop establishment methods in a rice-wheat rotation in North Western IGP. Field Crops Res., 116: 260-267

Siddique, K.H.M., Tennant, D., Perry, M.W. and Belford, R.K. (1990). Water use and water use efficiency of old and modern wheat cultivars in a Mediterranean-type environment. Aust. J. Agric. Res., 41: 431-447

Sidhu, H.S., Manpreet, S., Humphreys, E., Yadvinder, S., Balwinder, S., Dhillon, S.S., Blackwell, J., Bector, V., Malkeet, S. and Sarbjeet, S. (2007). The Happy Seeder enables direct drilling of wheat into rice stubble. Aust. $J$. Exp. Agric., 47: 844-854

Sharma, R.K., Chhokar, R.S., Jat, M.L., Samar, S., Mishra B. and Gupta, R.K. (2008). Direct drilling of wheat into rice residues: experiences in Haryana and West- ern Uttar Pradesh. In: Humphreys, E., Roth, C.H. (Eds.), Permanent Beds and Rice-residue Management for Rice -Wheat Systems in the Indo-Gangetic Plain. Proceedings of a Workshop held at PAU, Ludhiana, India from 7-9 September, 2006. ACIAR Proceedings No. 127, pp. 147-158, retrieved from http://www.aciar.gov.au/ publication/term/18

Singh, B., Eberbach, P.L., Humphreys, E., and Kukal, S.S. (2011). The effect of rice straw mulch on evapotranspiration, transpiration and soil evaporation of irrigated wheat in Punjab, India. Agric Water Manage., 98: 1847-1855

Singh, B., Eberbach, P.L, and Humphreys, E. (2014). Simulation of the evaporation of soil water beneath a wheat crop canopy. Agric Water Manage., 135: 19-26

Singh, M., Bhullar, M.S. and Chauhan, B.S. (2015a) Influence of tillage, cover cropping, and herbicides on weeds and productivity of dry direct-seeded rice. Soil Till. Res., 147: 39-49

Singh, M., Bhullar, M.S. and Chauhan, B.S. (2015b). Seed bank dynamics and emergence pattern of weeds as affected by tillage systems in dry direct-seeded rice. Crop Prot., 67: 168-177

Yadvinder, Singh., Sidhu, H.S., Manpreet-Singh., Humphreys, E., Kukal, S.S. and Brar, N.K. (2008). Straw mulch, irrigation water and fertiliser $\mathrm{N}$ management effects on yield, water use and $\mathrm{N}$ use efficiency of wheat sown after rice. In 'Permanent beds and riceresidue management for rice-wheat systems in the Indo -Gangetic Plain'. In: Humphreys, E., Roth, C.H. (Eds.), Proceedings of a workshop held in Ludhiana, India, 7-9 September 2006. ACIAR Proceedings No. 127. Australian Centre for International Agricultural Research (Canberra, Australia), pp. 171-181 retrieved from http://www.aciar.gov.au/publication/term/18. 
Rajan Bhatt and S.S. Kukal / J. Appl. \& Nat. Sci. 9 (1): 222 - 229 (2017)

Yao, S., Xiaolong Teng. and Bin, Zhang (2015). Effects of rice straw incorporation and tillage depth on soil puddlability and mechanical properties during rice growth period. Soil Till Res., 146: 125-132

Yunusa, I.A.M., Belford, R.K., Tennant, D. and Sedgley, R.H. (1993). Row spacing fails to modify soil evapora- tion and grain-yield in spring wheat in a dry Mediterranean environment. Aust. J. Agric. Res., 44: 661-676

Zheng, L., Wu, W., Wei, W. and Hu, K. (2015). Effects of straw return and regional factors onspatio-temporal variability of soil organic matter in a high-yielding area of northern China. Soil Till. Res., 145: 78-86 